Jaanika Anderson, Hilkka Hiiop

\title{
THE TRIPLE POMPEJANUM POSSESSED \\ BY THE VON STRYK FAMILY: THE MANOR HOUSES OF VANA-VÕIDU, SUURE-KÕPU AND VOLTVETI
}

\section{INTRODUCTION}

The extensive excavations of the legacy of ancient Rome in the $18^{\text {th }}$ century influenced the visual culture throughout Europe from Germany to Italy and England to Scandinavia, causing a real boom in the interpretation, adaptation, imitation and replication of antique architecture, interiors, applied art and literature. Antiquity became an indirect source of inspiration for all European visual culture, and was also directly quoted and copied. ${ }^{1}$ The newly excavated houses of prominent Romans were often decorated with paintings and sculptures, like museums, and served as inspiration for modern people. ${ }^{2}$ Graphic art, the predecessor of contemporary media, became the mediator of the new discoveries, ideas and inventions. ${ }^{3}$ Even

DOI: https://doi.org/10.12697/BJAH.2017.13.08

1 Peter Werner, Pompeji und die Wanddekoration der Goethezeit (München: Wilhelm Fink Verlag, 1970), 14.

2 Umberto Pappalardo, The Splendor of Roman Wall Painting (Los Angeles: The Paul Getty Museum, 2008), 12.

3 Anu Allikvee, "Piranesi and his time", Varemed. Ruins, ed. by Juhan Maiste, Kadi Polli (Tallinn: Eesti Kunstiakadeemia Restaureerimiskool, 2004), 214-232. 
Estonia, far away from the heart of Europe, was influenced by the interior décor discovered in the ancient cities of Italy.

There are several examples of interiors in Estonia that were inspired by antiquity: the colours, decorative schemes, individual motifs or combinations thereof. Pompeian wall paintings enjoyed their peak popularity from the last quarter of the $18^{\text {th }}$ century to the first half of the $19^{\text {th }}$ century. During fashion trend, public spaces like the University of Tartu Art Museum, as well as the interiors of several private townhouses and manor houses owned by Baltic Germans, were decorated with Pompeian-style wall paintings. Although the Baltic Germans travelled in Europe and visited the ancient cities, more often they were exposed to the antique murals when they visited their homeland, Germany, or St. Petersburg that was the closest city brimming with ideas. In addition, different printed sources were available to provide inspiration for decorating their houses using Pompeian-style wall paintings in the more formal rooms.

This article is inspired by the fascinating findings and conservation work done on Pompeian murals in Estonian manor houses ${ }^{4}$ during the last few decades, as well as the well-known decorations in the University of Tartu Art Museum in the university's main building ${ }^{5}$ and in private townhouses. ${ }^{6}$ The focus is on the murals in the manor houses of Voltveti, Suure-Kõpu and Vana-Võidu - all of which belonged to different members of the von Stryk family of Baltic Germans. The wall paintings in these late neoclassical manor houses were made during the second half of the $19^{\text {th }}$ century and inspired, in all cases, by a desire to achieve the look of an ancient interior. There are Pompeian-style murals in all three manors.

The article focuses on the figurative paintings and the style of the murals, as well as on an art-history-related interpretation and a wider contextual analysis of the Vana-Võidu wall paintings. These finds

4 Krista Kodres, Juhan Maiste, "Purilast Inglisteni. Seinamaalingute leiud mõisates", Kunst, 70/2 (1987), 42; Hilkka Hiiop, "In the Footsteps of Classical Antiquity. Influences of the Antique in Estonian Manor Murals", Baltic Journal of Art History, 3 (2011), 225-252.

5 Inge Kukk, "Pompejanum Tartu Ülikooli Kunstimuuseumis: üks haruldane interjöörinäidis",

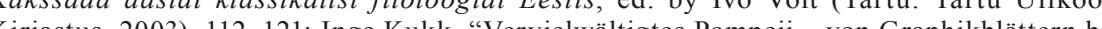
ur Wanddekortion", Baltic Journal of Art History, 3 (2011), 181-213.

6 In the beginning of the current decade, Pompeian-style wall paintings were discovered in a house belonging to Nicolai von Oettingen (1826-1876) in Vallikraavi Street in Tartu. The paintings were made in the second half of the $19^{\text {th }}$ century. See: Urmas Jaagant, "Tartus avasta aliharuldased vanad Pompei stiilis seinamaalingud", Eesti Päevaleht, 23.05.2013.
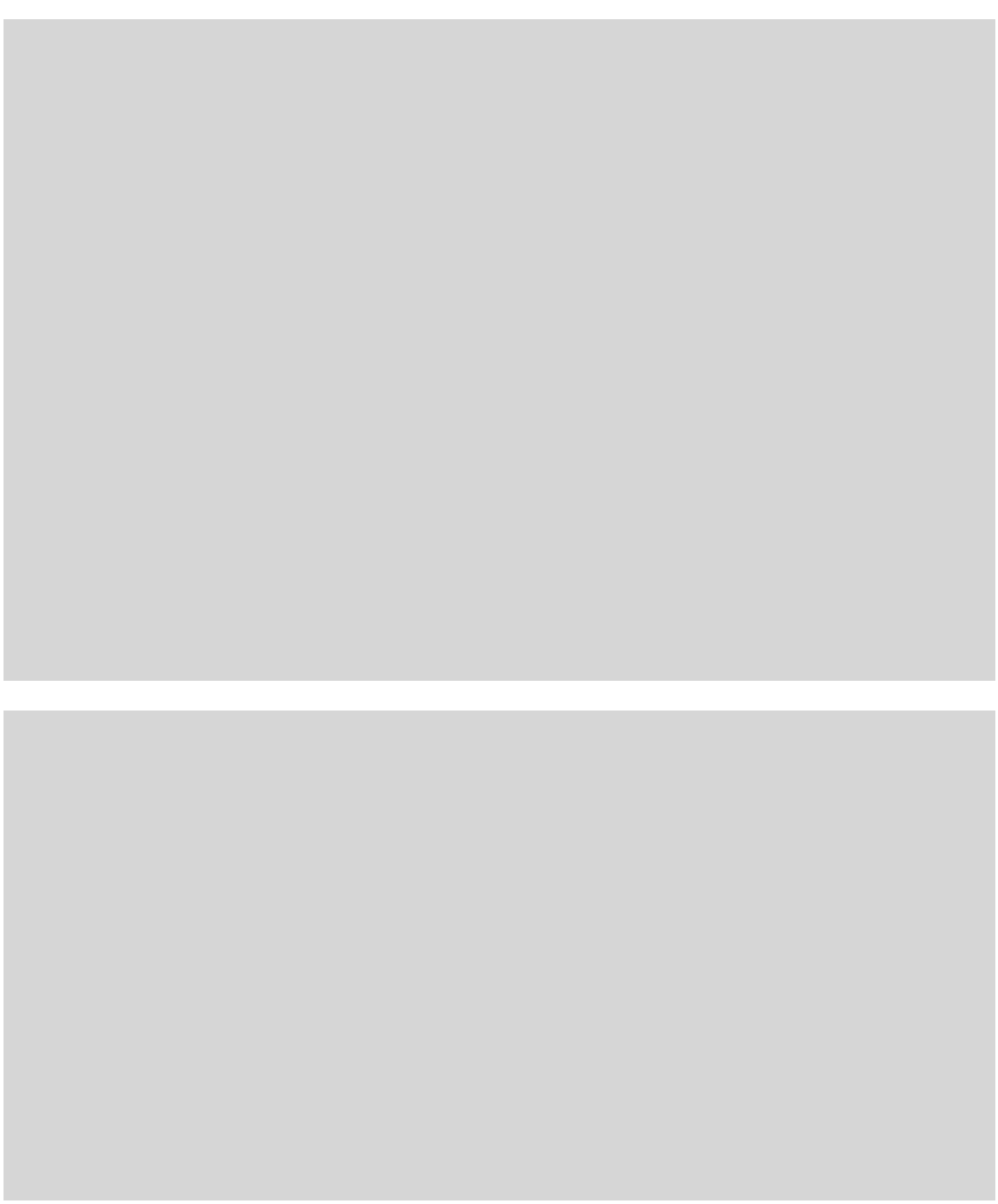

Fig. 1. Suure-Kõpu Manor. Photo: Juhan Maiste. Fig. 2. Vana-Võidu Manor. Photo: Juhan Maiste.

are the most recent, and this article will try to study the possible models and ideas for them, search for their art history context and importance among the triple Pompejanum of the von Stryks. The wall paintings in the Suure-Kõpu and Voltveti manor houses are used as reference material. 
The purpose of the paper is not to study the history of the von Stryk family beyond what is necessary for investigating the development of the interior of the manor and does not provide all the details about the discovery and conservation of the murals. ${ }^{7}$

\section{THE MODELS ARE MADE AVAILABLE}

During the $18^{\text {th }}$ and $19^{\text {th }}$ century, the Vesuvian cities and their treasures were being gradually revealed to a wider public. The decorations of the ancient rooms revealed previously unseen wealth and variety, being in an excellent state with well-preserved vivid and bright colours. Pompeian interiors continued to be vogue even during the early $20^{\text {th }}$ century. ${ }^{8}$

Excavations in the cities of ancient Rome triggered a boom of imitation and adaptation in architecture, interior design, the fine and applied art, as well as literature. Although inspiration was drawn directly from the rediscovered classical culture, the circle of intermediary sources was much broader. This European fashion trend did not leave Estonia untouched and emerged vividly in the Estonian manor houses. ${ }^{9}$

News about the discoveries in Herculaneum came first in the form of reports and printed versions of letters from eminent visitors. Publications by the antiquarians Antonio Francesco Gori (1691-1757), Ridolfino Venuti (1705-1763), Charles de Brosses (1709_ 1777) and Jean-Baptiste Requier (1715-1799) launched a flood of literature about the discoveries, but these publications were not well

7 For more about the discovery and conservation work, see: Krista Kodres, Värv Eesti arhitektuuris. Voltveti mõisa maalingud, VIII. Manuscript (Tallinn, 1985). Archive of National Heritage Board, A-1412; Voltveti môisa peahoone siseviimistlusuuringute aruanne, Vol. 1-2,
compiled by the Estonian Academy of Art / Tartu Art College (Hilkka Hiiop, Maris Suits, Heli Tuksam) (Tallinn: Eesti Kunstiakadeemia, H\&M Restuudio, 2010). Archive of National Heritage Board, A-9300. Hilkka Hiiop, Helina Torv, Eva-Liisa Lobu, Erle Kaur, Elise Lekarkin, Annabel Kongas, Anne Raud, Saara Kruus, Taavi Tiidor, Joel Leis, Vana-Võidu mõisa peahoone söögisaali ning ümbritsevate ruumide (suur saal, vestibüül, ruumid 208/210) siseviimistluse uuringud ja osaline restaureerimine. Aruanne (Tallinn: Eesti Kunstiakadeemia, H\&M Restuudio, 2016) Archive of National Heritage Board, A-13143.

8 Sebastian Schütze, “'Rome is simply a vast museum; Pompeii is living antiquity". The art of vesuvian cities between appropriation and reinterpretation ", Fausto \& Felice Niccolini: Houses and Monuments of Pompeii = Häuser und
de Pompei. (Köln: Taschen 2016), 66-77.

9 See more: Hilkka Hiiop, “Antiigi peegeldus Eesti mõisamaalingutel", Eesti kunsti ajalugu 1770-1840, 3 (Tallinn: Eesti Kunstiakadeemia, 2017), 288-298. illustrated.$^{10}$ From $18^{\text {th }}$ to the $19^{\text {th }}$ century, the results of excavations in Pompeii, Stabiae, Herculaneum and the other cities of Campania were published. Several generations of artists and architects worked to publish topographical depictions of the territories surrounding the volcano and to document new findings. The illustrations helped to shape the reception of the Roman antiquities and the buried cites. $^{11}$

The earliest systematic attempts to record the finds from these archaeological excavations, and to present image sheets of the Pompeian-style wall paintings appeared in Naples as Le antichità di Ercolano esposte (Part 1-8 in 1757-1792). The illustrations were not coloured but observed the practice of reproducing the colours as varying weights and textures of black lines to create a grisaille image of the original. ${ }^{12}$ This was followed by a two-volume publication by William Gell (1777-1836), an English classical archaeologist and illustrator, which was called Pompeiana. The Topography of Edifices and Ornaments of Pompeii, 1817-1818. The French architect and archaeologist François Mazois (1783-1826) set a new standard with a systematic and scientific approach based on a totally new study of the ruins. ${ }^{13}$ He published it in his Les ruines de Pompéi (Part 1-4 in 1824-1838) that included colourful prints in four folios ${ }^{14}$, and was the first to include all aspects of the Pompeian architecture. The first volume features the streets, city walls and tombs; the second focuses on the private houses; the third one is about the portico behind the theatre; and the fourth volume about the temples. ${ }^{15}$ The German architect and painter Wilhelm Johann Karl Zahn (1800-1871) published Die schönsten Ornamente und merkwürdigsten Gemälde aus Pompeji, Herculanum und Stabiae: nach einigen Grundrissen und Ansichten nach den an

10 Claire L. Lyons, Marcia Reed, "The Visible and the Visual: Pompeii and Herculaneum in the Getty Research Institute Collections", Antiquity Recovered: The Legacy of Pompeii and Herculaneum, ed. by Victoria C. Gardner Coates, Jon L. Seydl (Los Angeles: Getty Publications, 2007), 134.

11 Ibidem, 133-155.

12 Ibidem, 137-138.

13 Ibidem, 140

14 The University of Tartu Art Museum has an incomplete set of coloured sheets from Mazois's publication, www.muis.ee [viewed 26.02.2017].

15 Eric M. Moormann, Pompeii's Ashes: The Reception of the Cities Buried by Vesuvius in Literature, Music, and Drama (Boston, Berlin, Munich: De Gruyter, 2015), 55. 
Ort und Stelle gemachten Originalzeichnungen (Part 1 in 1828/1829, Part 2 in 1842/1844, Part 3 in 1852/1859) and a special collection of decoration called Ornamente aller klassischen Kunst-Epochen nach den Originalen in ihren eigenthümlichen Farben (1849) ${ }^{16}$, ten years after the first chromolithographs were printed in 1818. His massive project was a pioneering work that reproduced the paintings of Pompeii, Herculaneum and Stabiae. It was very successful and his printer successfully maintained the register by using seven different inks. ${ }^{17}$

The dramatic discoveries made in the lost Roman cities of Herculaneum from 1738 and Pompeii from 1748 onwards, which had been buried by an eruption of Mount Vesuvius in AD 79, inspired a succession of experiments in the design of interior furnishings, as well as other areas of neoclassical art. ${ }^{18}$ After the five huge volumes of Le antichità di Ercolano esposte were published, the neoclassical style spread throughout Europe. Robert Adams was one of the proponents of the reawakened interest in antiquity during the second half of the $18^{\text {th }}$ century. ${ }^{19}$ This resulted in new rules for the conceptualisation of architecture and interior design. ${ }^{20}$

On-site reconstructions were common in Pompeii after the excavations: houses are partially rebuilt, roofs and columns re-erected. Alternatively, ruined houses were 'rebuilt' in new locations, far from Italy ${ }^{21}$ : a Pompeian court was erected in London's Crystal Palace ${ }^{22}$, the Pompejanum in Aschaffenburg ${ }^{23}$, 16 These colourful publications were available in Estonia in $19^{\text {th }}$ century. The University of the Art Museum of Estonia has the first and second volumes.

17 See more details about his first chromolithographs in Bamber Gascoigne, Milestones in Colour Printing 1457-1859: With a Bibliography of Nelson Prints (Cambridge, New York, et al.: Cambridge University Press, 1997), 25-26

18 Encyclopedia of Interior Design, Vol. 1-2, ed. by Joanna Banham (London, New York: Routledge, 1997), 980

19 E.g. Steven Parissien, Adam Style (London: Phaidon, 1996).

20 Enrico Colle, "The Evolution of Pompeian Tastes in Europe", Houses and Monuments of Pompeii: The Works of Fausto and Felice Niccolini, ed. by Roberto Cassanelli, Pier Luig Ciapparelli, et al. (Los Angeles: The J. Paul Getty Museum, 2002), 26.

21 Pompeii in the Public Imagination from its Rediscovery to Today, ed. by Shelly Hales, Joanna Paul (Oxford: Oxford University Press, 2011), 7.

22 Opened in 1854, destroyed 1935.

23 An idealised replica of a Roman villa was completed in 1848 . the Maison Pompéienne in Paris ${ }^{24}$, Getty Villa in Malibu ${ }^{25}$, and the Pompeian-style residence called the Materialgåden, home of the Danish sculptor Hermann Ernst Freund (1786-1840) ${ }^{26}$, in Copenhagen. Several manor houses in Estonia also had rooms decorated in the Pompeian style.

Antiquity as a style may be an idealisation of the past. It may even be an attempt to dress up modern ideas in the clothing of that era. This reception of antiquity often includes a utopian aspect, whether looking to the past or the future. In many instances, it is possible to point to ancient models, but their influence may be more adaptive or eclectic. ${ }^{27}$ Furthermore, it is important to remember that the reception of antiquity is not always follow a straight line from antiquity to the creator of a product inspired by antiquity. ${ }^{28}$ In the case of the Pompeian interiors in the Estonian manor houses, we should keep in mind that news reached Estonia through various intermediaries. These included the Baltic-German landlords who travelled and were familiar with the fashions in Europe; St. Petersburg, which was the closest city providing inspiration ${ }^{29}$, and the books publishing information about the new finds of ancient materials that were available in Estonia. ${ }^{30}$

24 The house was completed in 1860 and demolished in 1891

25 It was opened in 1954

26 His decoration program found inspiration in Wilhelm Zahn's recently published booklets presenting lithographic reproductions of entire reconstructed or authentic interiors from Pompeii, but eclectically juxtaposed the single elements related to the particular characteristics of his residence. Kristen Nørregaard Pedersen, "Pompeian Decorative Art in the Danish Golden Age. Conceptual Background and Development of Motive", Acta Hyperborea, 2 (Copenhagen, 1990), 140.

27 Hans Erik Mathiesen, "The Reception of Classical Antiquity: Some General Remarks", Acta Hyperborea, 2 (Copenhagen, 1990), 20

28 Ibidem, 23.

29 Pavlovsk Palace and its park became, in simplified form, an example for many Baltic manors A number of Baltic Germans served in the military and state administration at the Russian mperial court. Therefore it is possible to follow the movement of the fashion from Russia to the des Rokoko und Klassizismus", Maarjamn, "Candidatus Pictura. Gottlieb Welté als Künstle by Anne Untera (Tallinn: Printon, 2007), 78

30 Hilkka Hiiop, "Antiigi peegeldus Eesti mõisamaalingutel”, 289. 


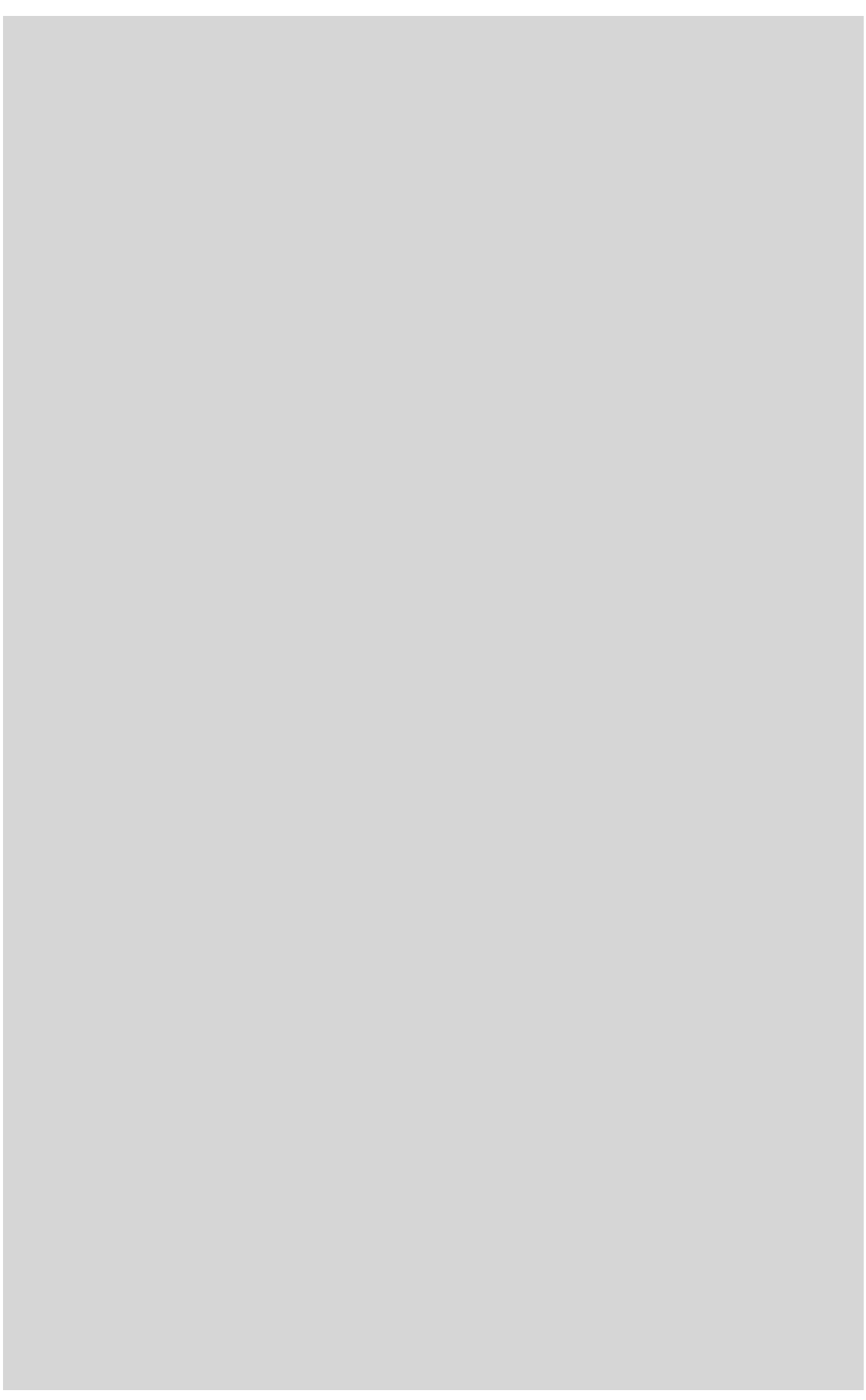

Fig. 3. Voltveti Manor. Wall paintings on the lambris of the ballroom. Photo: Martin Siplane (2010).
Fig. 4. Wall paintings on the mirrored ceiling of the ballroom. Photo: Martin Siplane (2010).

\section{THE THREE MANOR HOUSES OF THE VON STRYK FAMILY - THE TRIPLE POMPEJANUM}

Manor owner Bernhard Heinrich von Stryk (1746-1829) was the son of Andreas Wilhelm von Stryk and Gertruta von Vietinghoff. He served in the Army of the Russian Empire and retired as a lieutenant in 1768. After that he started to buy or took over the mortgages of several manors: in 1773 he bought the Riidaja (Morsel) Manor, in 1775, the Puka (Alt-Bockenhof) Manor, in 1786, Voltveti (Tignitz) and Kärsu (Kersel), in 1805, Suure-Kõpu (Gross-Köppo) and in 1819 Taagepera (Wagenküll) Manor. ${ }^{31}$ Bernhard Heinrich married Anna Elisabeth von Oettingen (1763-1825) in 1782 and they were blessed with 11 children.

Three of their sons are the focus of this article. They became the landlords of estates in Livonia, and all the manors were situated relatively short distances from each another. Their manor houses are united by the fact that, during the last ten years, murals in the Pompeian style have been discovered in all of them. The murals have been partially or fully revealed and restored, but last find in VanaVõidu is still full of surprises, as the probing of the paint layers has shown.

Voltveti or Tihemetsa (Tignitz) estate in the Saarde Rural Municipality in Pärnu County is the first of the three manors owned by the von Stryk family. In 1784, Martin Friedrich von Krüdener, the owner of Voltveti, pledged his mansion to Bernhard Heinrich von Stryk. In 1786 a sales transaction took place and the Voltveti manor

31 Wolf-Dietmar von Stryk, Riidaja von Strykide perekonna põliskodu Liivi-ja Eestimaal 15621919-2003: ̈̈he mõisa ajalugu sajandite tagant tänase päevani (Riidaja: Põdrala Vallavalitsus, 
house was transferred to the von Stryk family. It remained in their possession until it was expropriated in 1919. The two-storied stone manor house in the late neoclassical style was built between the 1830s and 1840s, when the owner was Heinrich Franz Wilhelm von Stryk (1793-1862). In the middle of $19^{\text {th }}$ century, the manor was prospering thanks to the Heinrich Franz's brick factory, ${ }^{32}$ and the interiors of the house were completed. Voltveti was given to his son Alexander Oskar von Stryk (1830-1902) in 1866, who became a rich man. When he died, he was a millionaire due to his hard work and providence. ${ }^{33}$

During the investigative work in 1985, the wall paintings underneath the monochrome oil paint in the ballroom and adjacent room behind the vestibule were partially revealed, documented and recovered. ${ }^{34}$ The décor of the first layer probably dates back the time that the house was built. ${ }^{35}$ Voltveti is one of the three mansions of Stryk family with paintings supposedly inspired by antiquity.

The paintings in the halls of the Voltveti Manor reflect different historical epochs. In the hall behind the vestibule, the walls are divided into panels with painted frames and grotesque decorations derived from ancient vases are painted on the yellow-beige background. According to Krista Kodres, the primary source of inspiration for the painting in the hall behind the vestibule is the antiquity-based 'grotesque style', modelled after the wall paintings in the Domus Aurea in Rome. ${ }^{36}$

The ballroom features a mixed stucco décor with painted angel figures, Ionic columns and imitation marble. The middle of the wall features a painting in the grisaille technique with flower motifs, arranged symmetrically in the corners of the stucco panels. Yellow acanthus leaves, lyres and stylized figures, the faces of Medusa with a green colour alternating with laurel garlands tied with yellow ribbons - all painted in the grotesque style - can be seen on the mirrored ceiling. Ionic columns are depicted on the dado. ${ }^{37}$

32 Kodres, Maiste, "Purilast Inglisteni. Seinamaalingute leiud mõisates", 44.

33 Wolf-Dietmar von Stryk, Perekonna von Stryk-Tignitz ajaloost aastatel 1784-1920: môtteid ja tagasivaateid Tignitz-Voltveti-Tihemetsale (Viljandi: W. Stryk, 2002), 4-5.

34 The paintings in the vestibule have been destroyed.

35 Kodres, Värv Eesti arhitektuuris. Voltveti mõisa maalingud, VIII, 13.

36 Kodres, Maiste, "Purilast Inglisteni. Seinamaalingute leiud mõisates", 44; Hiiop, "In the Footsteps of Classical Antiquity. Influences of the Antique in Estonian Manor Murals", 247.

37 Voltveti mõisa peahoone siseviimistlusuuringute aruanne, Vol. 1-2.
Layers of paintings were also found in the other rooms, including stencil-paintings, the possible models for which may have come from Zahn's album. ${ }^{38}$ The publication had made a great impact, and was often used as a sourcebook for "interior decorations by house painters and craftsmen". ${ }^{39}$ In Voltveti, we can see the details of paintings, which are clearly modelled on antiquity, although the overall solution - the alternation of warm and cold pastel shades was not. ${ }^{40}$ There is no doubt that the inspiration was derived from antiquity, but we see a further development of the Pompeian style and the interior décor actually bears a greater resemblance to the Adams style. However, the information on Voltveti is incomplete, because the wall paintings have not been fully revealed and studied to the same extent as the paintings in Suure-Kõpu and Vana-Võidu.

Bernhard Heinrich bequeathed the Suure-Kõpu (Groß-Köppo) manor in Kõpu Rural Municipality, Viljandi County to his eldest son Alexander Georg Gottlieb von Stryk (1787 or 1788-1845), who married Juliane Charlotte Friederike von Dachenhausen (1773?-1825) in 1806. Two daughters were born to the couple. Eleven years after the death of the first wife, Alexander Georg married Amalia Helena von Maydell (1814-1843). Five more daughters and his heir Heinrich Otto Alexander von Stryk (1839-1903) were born into the family from the second marriage. ${ }^{41}$ The old manor house burned down in 1825 and Alexander Georg lived for a few years in the Viljandi Manor. The desire for a new manor house arose when he married a young woman in 1836. Alexander Georg began constructing a new twostoried late neoclassical manor house - one of the most prominent of its kind in South-Estonia. ${ }^{42}$ The manor, designed by Emil Julius

38 See examples of ornaments in Wilhelm Zahn, Ornamente aller klassischen Kunst-Epoche nach den Originalen in ihren eigenthümlichen Farben (Berlin: Dietrich Reimer, 1849), 145.

39 Valentin Kockel, "The Rediscovery and visualisation of Pompeii. The work by the Niccolin brothers and its context", Fausto \& Felice Niccolini: Houses and Monuments of Pompeii (Köln Taschen, 2016), 20.

40 Hiiop, "Antiigi peegeldus Eesti mõisamaalingutel", 297.

41 When the younger Alexander managed the manor, it was well-known for its art collection:

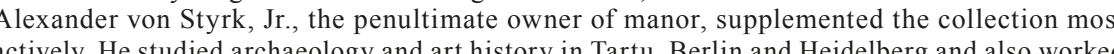

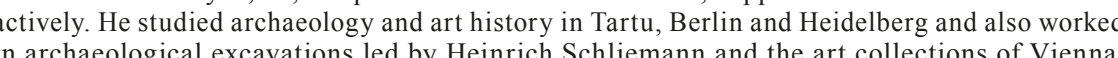
Ants Hein Viljandima moisad. The Manor Houses of Viljandi County. Estonia (Viljandi: Hattorpe, 1999), 65

42 Svea Volmer, Hilkka Hiiop, "Salapärane ja ihaldatud Pompei", Muinsuskaitse aastaraama 2007 (Tallinn: Muinsuskaitseamet, 2008), 56-60. 


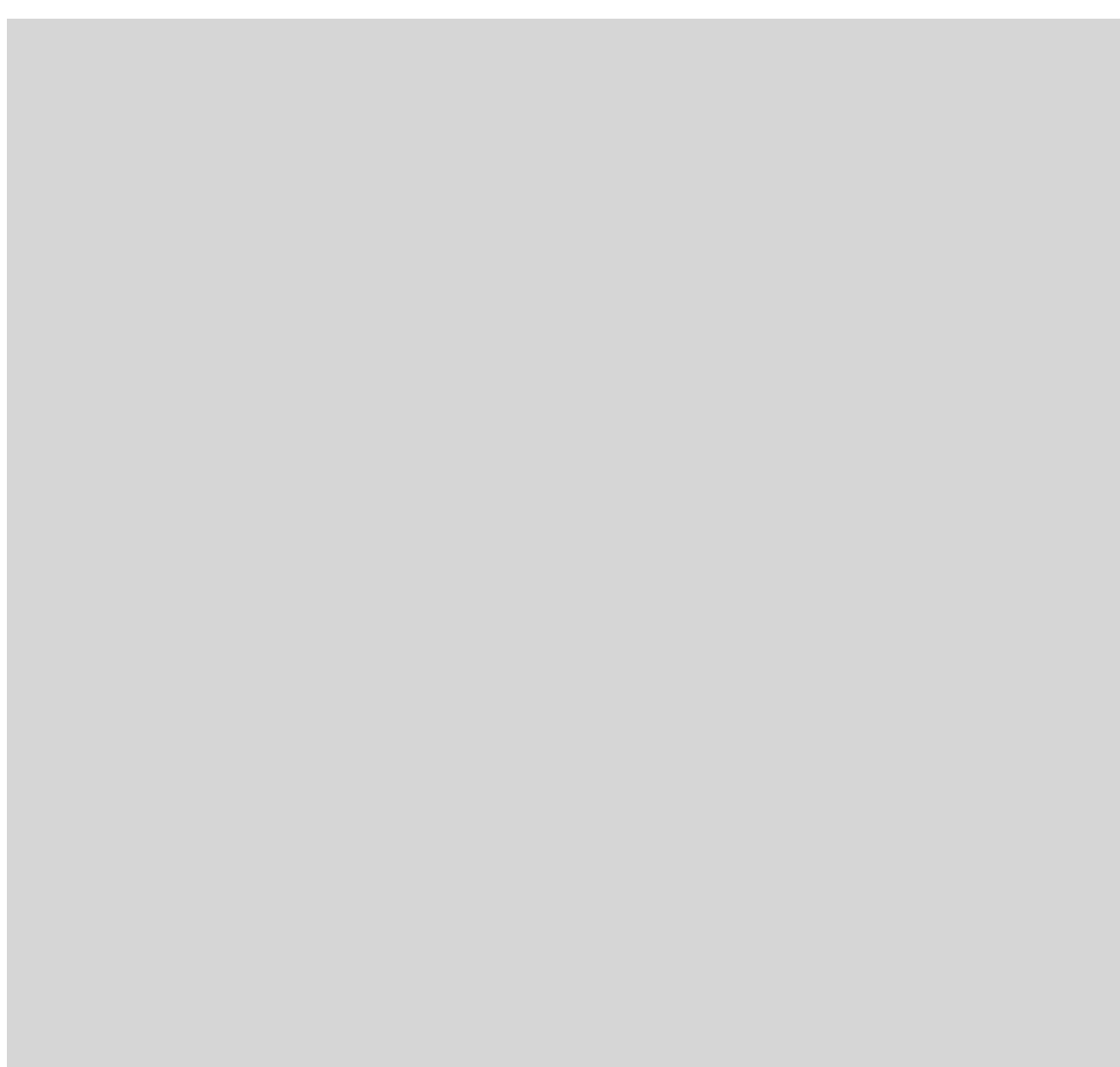

Fig. 5. Suure-Kõpu Manor. "Signature" of the painter in the dining room. Photo: Villu Plink (2010).

Strauss, the city architect of Mitau (Jelgava) ${ }^{43}$ was completed in 1847, after Alexander Georg's death. ${ }^{44}$

The most valuable part of the building is the interior décor, especially the series of figurative Pompeian-style paintings in the former dining hall, which is unique in the manorial architecture of Estonia. Years ago, only faded pinkish walls were visible in a bleak school assembly hall. All that remained of the murals were a legend

43 Emil Julius Strauss was also the architect of the Courland (Jensel) manor house that belonged to Alexander von Oettingen (1798-1846) from 1834. The late neoclassical manor house was built in $1836-1844$ and it is remarkably similar to the manor house of Suure-Kõpu. Ants Hein
suggests that Strauss was also associated with the building of the Vana-Võidu manor house. Hein, Viljandimaa mõisad, 65 .

44 Ants Hein, Eesti mõisaarhitektuur. Historitsismist juugendini (Tallinn: Hattorpe, 2003), 73.

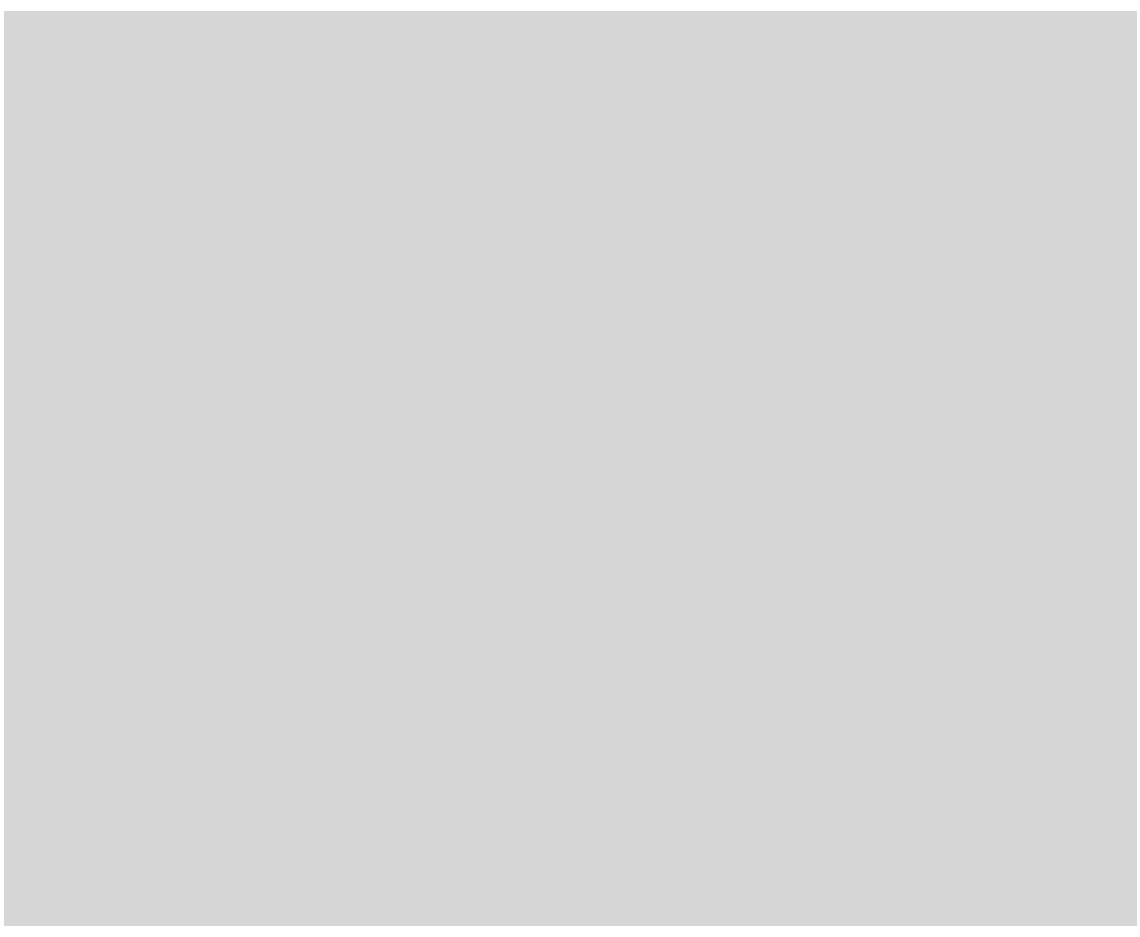

Fig. 6. Suure-Kõpu Manor. Dining room. Photo: Toomas Vendelin (Royal Norwegian Embassy, 2011).

and a single black-and-white photograph from the 1960s. A figurative scene would occasionally be uncovered during renovation work, but would be covered up again. The wall paintings were rediscovered in 2003 by the conservators and were fully revealed in $2006 .{ }^{45}$ Under layers of paint, an enchanting Pompeian-style black-and-red interior was gradually revealed.

Three figurative scenes with centaurs have survived in their entirety, one on the southern and two on the western wall. During the Soviet era, the door in the western hall was enlarged and thus the fourth panel lost a considerable part of its painted surface. The demolition of the northern wall probably destroyed one of the panels, which corresponded symmetrically to the painting on the southern wall. During the conservation project, the wall, cavetto vault and Manor Murals", 243-244. 


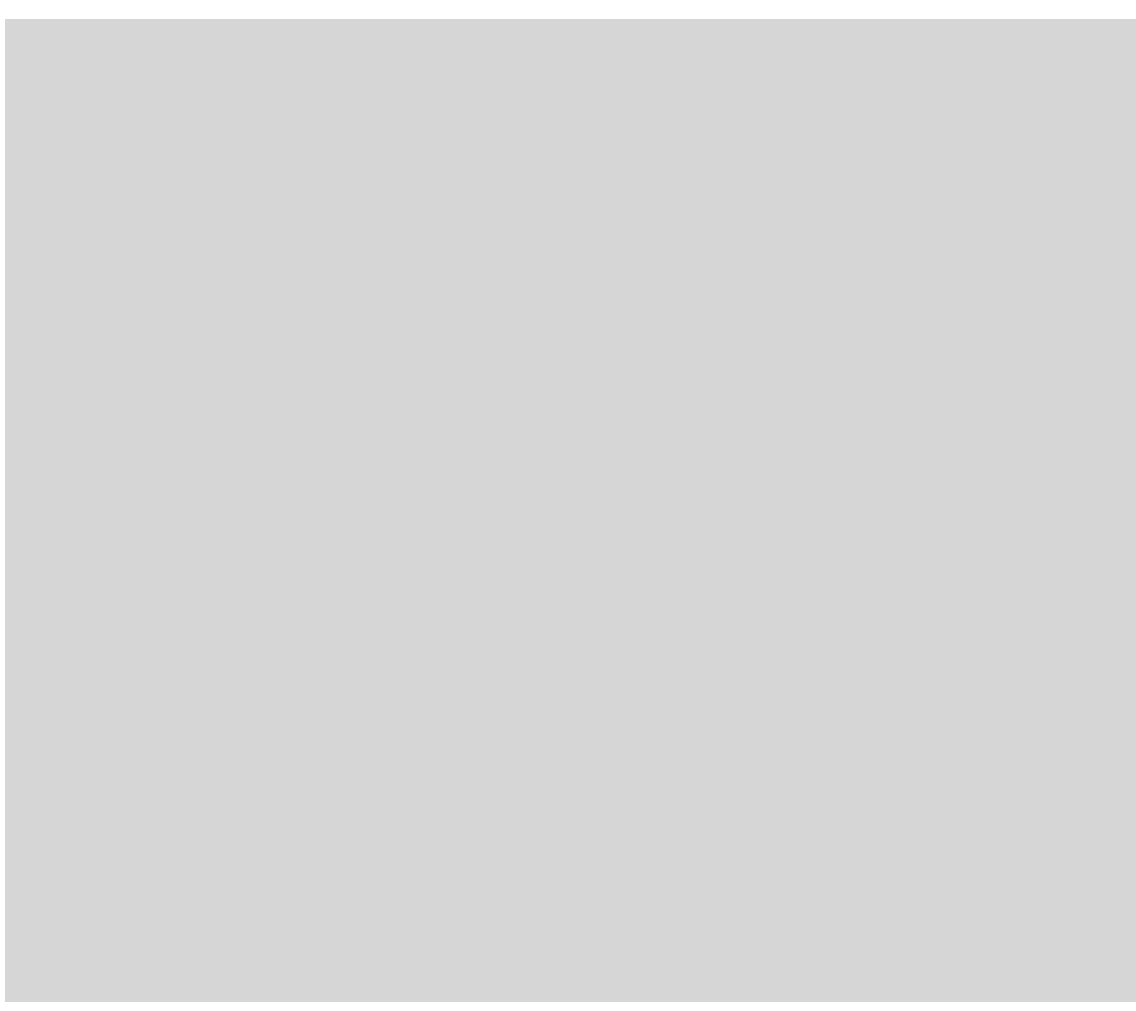

Fig. 7. Suure-Kõpu Manor. Murals in the dining room. Photo: Villu Plink (2010).

architectonic division of the décor were reconstructed, although the missing figures in the painted panels were not repainted. However visitors can admire them via a digital projection in the room. ${ }^{46}$

The mythological scenes depicting centaurs are copies of paintings from the Villa Cicero in Pompeii. The originals were excavated and removed in 1749. Since that time they have been stored in the National Archaeological Museum in Naples. ${ }^{47}$ The murals in the Villa Cicero inspired many $18^{\text {th }}$ and $19^{\text {th }}$ century artists, who produced numerous black-and-white and coloured graphic copies. The graphic models for the Suure-Kõpu artist supposedly come from Wilhelm Zahn's

46 See about conservation in Volmer, Hiiop, "Salapärane ja ihaldatud Pompei", 56-60.

47 Domenico Monaco, Les monuments du Musée National de Naples gravés par les meilleurs artistes Italiens (Neapel, 1877), 8, T 28, T 29, T 31. colourful albums..$^{48}$ Although the motifs had already been published earlier, for instance, in the four volumes of Le case ed $i$ monument $i d$ Pompei disegnati e descritti by Fausto and Felice Niccolini between 1854 and $1896 .{ }^{49}$ The figures of the centaurs in Suure-Kõpu are significantly larger than the originals in Villa Cicero. Therefore, it is quite possible that von Stryk had not actually seen the paintings. At any rate, it is remarkable that the Villa Cicero's small figurative scenes ended up as the wall décor in an Estonian manor house interior. ${ }^{50}$

In addition to the three centaurs, fragments of the central painting with a figure's head and wings on the western wall have also survived. The scene depicts Victoria, the Roman goddess of victory with a spear and shield. The mural was excavated in Casa dei Principi Russi in Strada Stabiae in $1852 .{ }^{51}$ In the Villa Cicero, as well in the SuureKõpu Manor, the scenes with centaurs have a black background. Black also forms the backdrop for the figure of Victoria although it was originally ochre yellow according to Zahn. ${ }^{52}$ The preserved details of the figure resemble those in Zahn's album. The scene with Victoria confirms that the murals could not have been finished in SuureKõpu before the 1850s because the album was not published earlier

The overall composition, with its architectural articulations, caryatids between the windows, marbled Corinthian orders dividing the panels, painted dentil moulding that creates an optical spatial effect, and the imitation graining on the ceiling comes from the artist's own imagination. ${ }^{53}$

48 Wilhelm Johann Karl Zahn, Die schönsten Ornamente und merkwürdigsten Gemälde aus Pompeji, Herculanum und Stabiae: nach einigen Grundrissen und Ansichten nach den an Ort und Stelle gemachten Originalzeichnungen (Berlin: Riemer, 1828-1859). For comparison, the murals in the University of Tartu Art Museum were completed in 1868 and the prints of the
Zahn's publication were also used as models.

49 See the monochrome centaurs in Fausto Niccolini, Felice Niccolini, Le case ed i monumenti di Pompei disegnati e descritti, Band 2 (Neapel, 1862), IIIa.

50 Hiiop, "In the Footsteps of Classical Antiquity. Influences of the Antique in Estonian Manor Murals", 246.

51 In Wilhelm Johann Karl Zahn, Die schönsten Ornamente und merkwürdigsten Gemälde aus Pompeji, Herculanum und Stabiae: nach einigen Grundrissen und Ansichten nach den an Ort und Stelle gemachten Originalzeichnungen, Band 3 (Berlin: Riemer, 1852/1859), Plate 94 an in Fausto Niccolini, Felice Niccolini, Le case ed i monumenti di Pompei disegnati e descritti, Band 1 (Neapel, 1854), strada Stabiana casa numero 57.

52 The same motif, the winged Victoria with the spear, was depicted on the wall of triclinium in the Moregine complex near Pompeii. Unlike the motif of the Casa dei Principi Russi, the background is red. The Moregine house and its paintings were discovered in 1959.

53 Hiiop, "In the Footsteps of Classical Antiquity. Influences of the Antique in Estonian Manor Murals", 246. 
The artistic quality of work suggests that it could not have been executed by a local master. This is also suggested by the self-portrait of the artist, which is concealed in the marbling of a pillar framing a field of the painting, and seems to portray a southern type. ${ }^{54}$

The Vana-Võidu Manor (Alt-Woidoma) is situated in the Viljandi Rural Municipality in Viljandi County. Georg Constantin von Stryk (1797-1886), the youngest son of Bernhard Heinrich, purchased the Vana-Võidu estate in 1834 . He wanted to make his new property more presentable, as did his brother Alexander Georg in SuureKõpu and his closest friend Alexander von Oettingen ${ }^{55}$, the brother of his both wives, in Courland. ${ }^{56}$ The manor house at Vana-Võidu was probably built in the $1840 \mathrm{~s}^{57}$ and the architect was probably the aforementioned, Emil Julius Strauss ${ }^{58}$, who was involved in the construction in Courland and Suure-Kõpu. The manor was well-off and bred cattle. In 1864, Georg Constantin bequeathed the manor to his son Georg Philipp von Stryk (1833-1893). Most likely the Pompeian-style murals in the small hall, probably the dining room, ${ }^{59}$ were painted during the 1840s or after 1864 when the manor house already belonged to Georg Philip. ${ }^{60}$

In 2016, research was carried out to identify the original decorations in the dining hall. Five so-called Pompeian motifs were discovered In total, there are eight motifs in the small hall, but three panels are behind a wall that was built later, and have yet to be uncovered. ${ }^{6}$ These motifs, which are the latest Pompeian-style murals to be found in Estonia, were revealed and restored on the walls of the Vana-

54 Hiiop, "Antiigi peegeldus Eesti mõisamaalingutel", 296.

55 He was married to both daughters of Franz Georg von Oettingen: at first, in 1820, he married Anna Elisabeth von Oettingen (1799-1821); after her death in 1826, he married her younge sister Amalie Friederike von Oettingen (1801-1873)

56 Hein, Viljandimaa mõisad, 73-74.

57 Heiki Raudla, Kilde Vana-Võidu ajaloost: lühike ülevaade Vana-Võidu ametikooli, valla ja mõisa ajaloost (Vana-Võidu: Viljandi Ühendatud Kutsekeskkool, 2011), 12

58 See fn 43 .

59 Hiiop, Torv, et al., Vana-Võidu mõisa peahoone söögisaali ning ümbritsevate ruumide (suu saal, vestibü̈̈l, ruumid 208/210) siseviimistluse uuringud ja osaline restaureerimine, 16-18.

60 Some of the possible model-sheets for wall-paintings were published already decades before

61 The dining room is separated in two by a wall. In addition, wall paintings have been identified in other rooms, including the vestibule. See: Hiiop, Torv, et al., Vana-Vôidu mõisa peahoone öögisaall ning ümbrisevate ruumide (suur saal, vestibü̈̈l, ruumid 208/210) siseviimistluse uringud ja osaline restaureerimine.
Võidu mansion. Previous observations and studies had shown that the condition of the painted panels was quite complicated. And they were not considered to be valuable or worth restoration. ${ }^{62}$ The results of the study (2006) were questioned because of the exposed areas of the paintings, and the fact that the family's neighbouring manor houses (Voltveti and Suure-Kõpu) have high-quality Pompeian-style wall paintings.

The decorations in the dining hall at Vana-Võidu copy the typical ancient wall diagram: a dado in the bottom zone (here, marbled); large dark coloured panels in the central zone; and colourful painted figural compositions in the upper zone. ${ }^{63}$ The figural scenes are placed into triangular frontons: motifs with birds and insects, a pigeon holding a letter, a parrot with a basket of treasure; and three fields depicting a chariot driven by different creatures, such as a butterfly and beetle. By contrast, compared with the dado and panels, the figurative paintings in the zone of frieze are unexpectedly wellpreserved. ${ }^{64}$ We observe five of the re-opened figurative paintings in the frieze zone some of which have derive their original models from antiquity.

Figural motifs are placed atop the windows and the door.

1. One of the most complete and best preserved motifs, depicting a parrot, chariot and a grasshopper, is atop the eastern door (Fig. 13). In addition to the paintings rediscovered in Herculaneum, a chariot with a charioteer and somebody pulling the chariot was a common motif in antiquity and also used in miniaturised form on gems ${ }^{65}$. On the mural in the hall of the Vana-Võidu manor house, the parrot is pulling the chariot while the grasshopper is the charioteer. An example of this motif - a chariot-driving grasshopper with a parrot - was also found on 10 October 1745 in the souterrain of Resina, Herculaneum. It was removed and exhibited at the Naples National Archaeological Museum

62 Nella Noorhani, Vana-Võidu mõisa peahoone siseruumide värvisondaažid (2006), 13. Archive of National Heritage Board, A-8114.

63 Compare this with the Suure-Kõpu paintings, where there is a light marbled dado, black central wall panels, and figurative paintings in the middle of the panels.

64 Hiiop, Torv, et al., Vana-Võidu mõisa peahoone söögisaali ning ümbritsevate ruumide (suur saal, vestibüül, ruumid 208/210) siseviimistluse uuringud ja osaline restaureerimine, 14.

65 Similar motifs are common on the gems e.g. Amor as charioteer driven by a lion, griffin as charioteer is driven by fowls shows a cricket driving a chariot drawn by two hounds. Adol Furtwängler, Die antiken Gemmen. Geschichte der Steinschneidekunst im klassischen Altertum, Band 1 (Leipzig, Berlin: Giesecke \& Devrient, 1900), T XLII.35, XLVI.39, 45. 

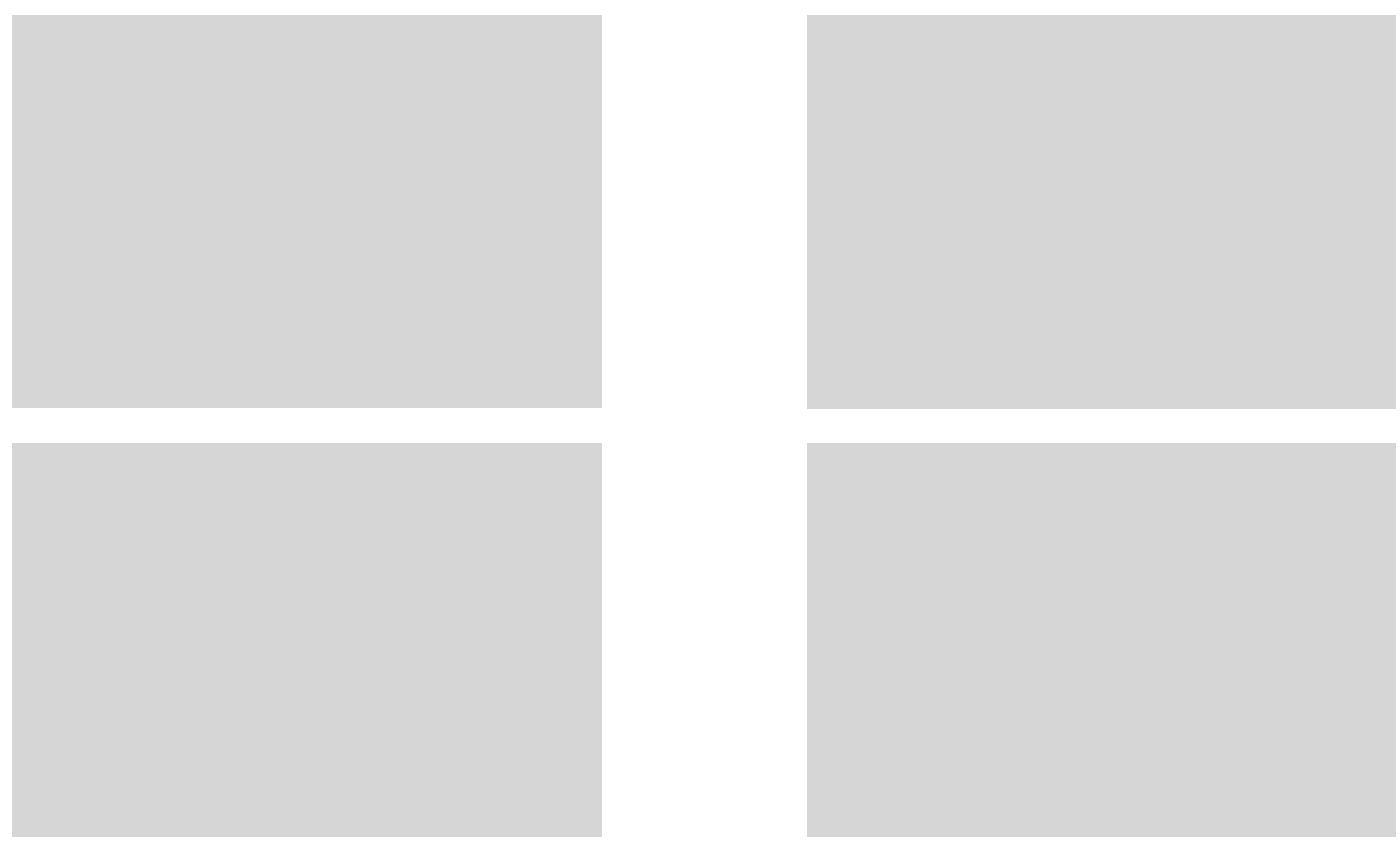

Fig. 10.-11. Vana-Võidu Manor. Figurative details of the wall paintings. Photos: Peeter Säre (2016) 


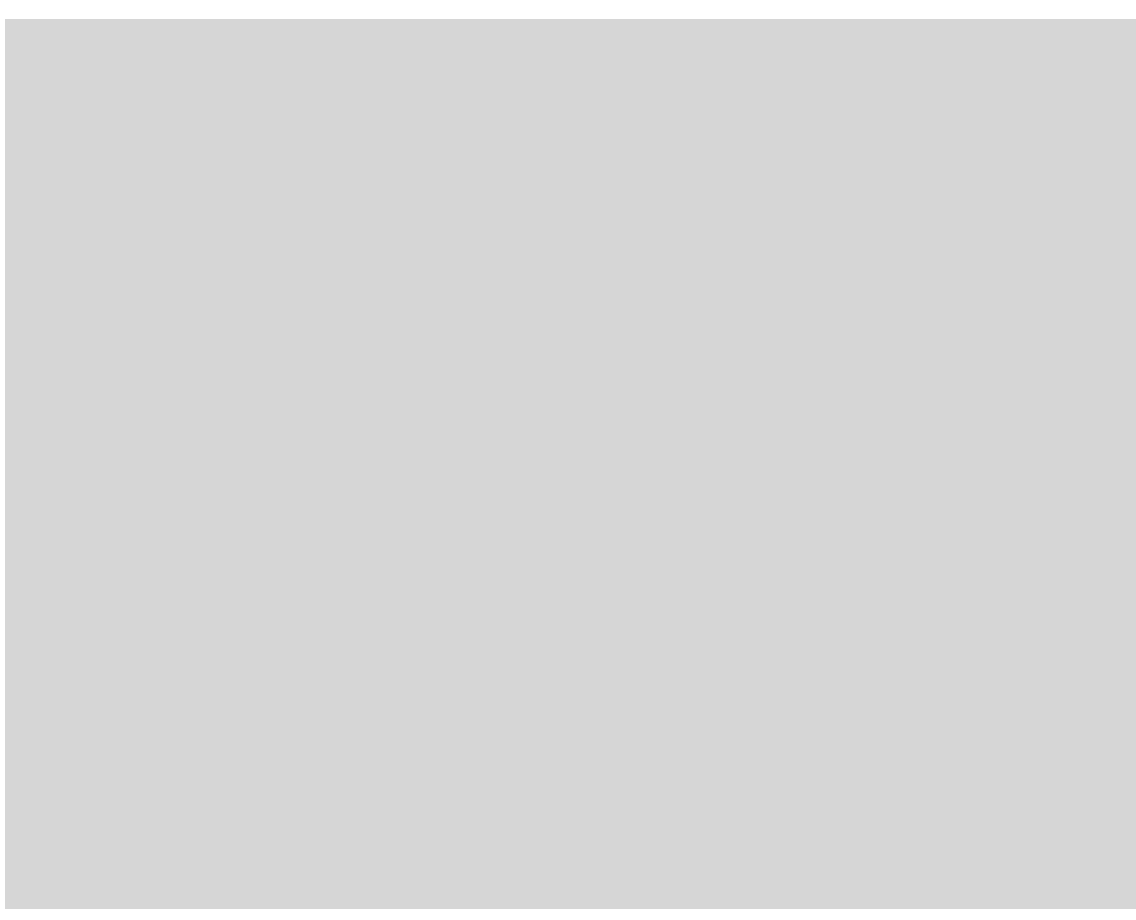

Fig. 12. Parrot and grasshopper from Herculaneum. Le Antichità di Ercolano Esposte, Vol. 1 (Naples, 1757), 247.

but no longer exists. ${ }^{66}$ The motifs of the paintings were published for the first time twelve years after the excavations, ${ }^{67}$ and engravings of the finds from the ruins of Herculaneum were included. ${ }^{68}$ (Fig. 12.) The engravings are of high quality and the accompanying text indicates great scholarship, but the book lacks the information on context that would be expected in today's archaeological work. The publication was designed more to impress its readers with the quality of the objects in

66 The Natural History of Pompeii, ed. by Wilhelmina Feemster Jashemski, Frederick G. Meyer (Cambridge: Cambridge Univesity Press, 2002), 232.

67 Le Antichità di Ercolano Esposte, Vol. 1 (Naples, 1757), 245-247.

68 The motif of a parrot and grasshopper is described in a publication translated into English as The Antiquities of Herculaneum, transl. by Thomas Martyn and John Lettice (London. Printed for S. Leacroft, 1773), plate XLVII, 192-195: "The pictures which are engraved in this plate do not seem to require any explanation. What is here represented is so clear, that it may be easily understood at first sight. If anyone however would consider them with a more attentive eye, he cannot but admire the taste and fancy of the painter. In the first we see a partot executed with much grace and beauty, drawing a little car, and guided by a gryllid, holding the reins in its
mouth. It is not unusual to see these pleasantries or allusions upon gems, and even upon medals."

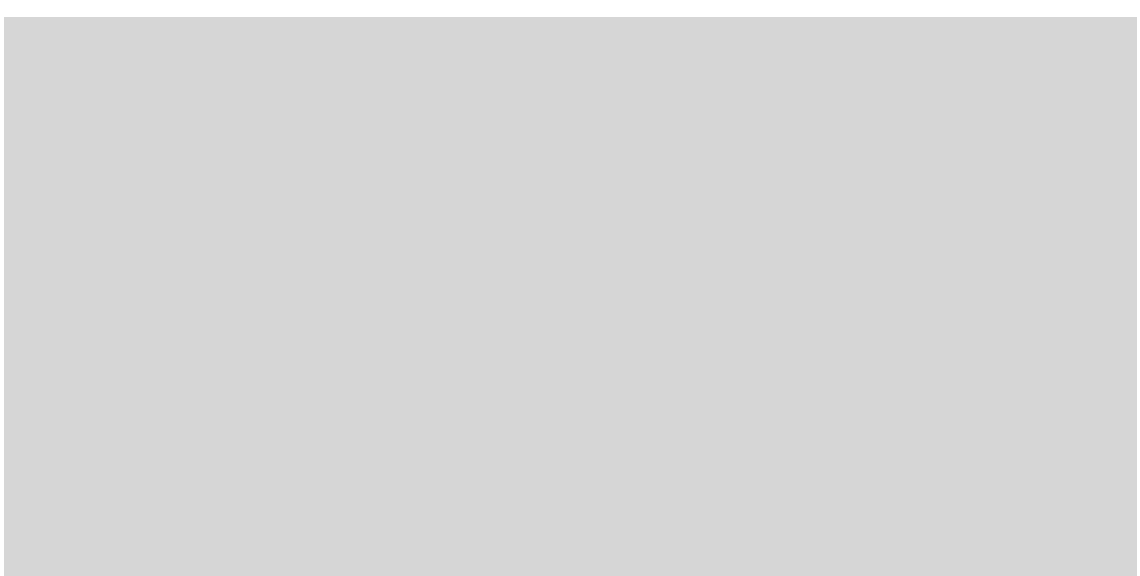

Fig. 13. Vana-Võidu Manor. Figurative details of the wall paintings. Photo: Peeter Säre (2016).

the King of Naples' collection than to be used for research. The book provided impetus to the neoclassical movement in Europe by giving artists and decorators access to a huge store of ancient motifs. It is not sure which publication was available to von Stryk, to serve as an example for the mural with the parrot and grasshopper. ${ }^{69}$

The wall painting of a parrot drawing a cart driven by a grasshopper, is caricature-like. The Romans enjoyed teaching their pets tricks. However an image preserved in lava from ancient Herculaneum, depicting a miniature chariot drawn by a parrot and driven by a grasshopper, was meant as satire ${ }^{70}$, i.e. the stronger being driven by the weaker. It has been said that this referred to the

69 1782, the same motif was published once again in France: Jean Claude Richard de Saint-Non, Voyage Pittoresque Ou Description Des Royaumes De Naples Et De Sicile (Band 2): Contenant Une Description des Antiquités d Herculanum, des Plans \& des Détails de son Théatre, avec une Notice abrégé des différens Spectacles des Anciens. Les Antiquités de Pompeïi [...] (Paris, 1782), 14a.

70 Rainbow colours, a squawk, a powerful hooked bill and the ability to mimic the human voice are hallmark traits of the parrot species that have fascinated people since antiquity. The ancient Greeks brought parrots from India - possibly both the Rose-Ringed Parakeet, which is depicted on the Vana-Võidu wall painting, and the larger Alexandrine Parakeet. The ancien Romans kept both Rose-Ringed Parakeets and African Greys. The parrot was an expensive much-loved household pet in Rome, because they had human tongues, and could be trained to speak by professional trainers. As well as everyday sayings, the parrots vocabularies included greetings and obscenities. They are highly trainable, dexterous and acrobatic, using their powerful bill and zygodactyl toes to grasp and clinmb in search of fruth, seeds a and buds in the wild. Rachel Warren-Chadd, Marianne Taylor, Birds: Myth, Lore and Legend (London: Bloomsbury Publishing PLC, 2016), 150 . 
influence that Seneca had over Nero. ${ }^{71}$ It can be interpreted as a satiric allegory of Emperor Nero, who said that one of his principal talents was singing in public theatres and who placed greater importance on being a good charioteer than on running an empire, and of the philosopher Seneca, who is characterised as being strong in rhetoric but weak in action..$^{72}$ Others, with more reason, have seen in this the famous witch Locusta as the grasshopper ${ }^{73}$ that provided Nero with the poison to murder his stepbrother Britannicus. ${ }^{74}$ The chariot depictions may also be parodying the triumphant entries of rulers into Rome. ${ }^{75}$

In this case, it is possible that it is the only existing colour reproduction of the motif. Only black-and-white images have been preserved by the engravings in early publications. Therefore, we do not know the original colours of this figurative painting.

2. Another motif with a chariot is fragmentary - the winged insect seems to be a charioteer whose chariot is being driven by a creature that also has wings - a greif with the body, tail and legs of a lion and wings of an eagle is harnessed to the chariot. ${ }^{76}$ (Fig. 11.) A model for the motif was preserved in the Naples National Archaeological Museum and can be found published along with the parrot and the grasshopper. (Fig. 14.) On the sample sheet, there is a winged insect which is undoubtedly a butterfly, but on the wall in the Vana-Võidu manor house, it has assumed the shape of European mantis in the flying position.

71 Nero (37-68 AD) became Roman Emperor at the age of 17. In the first year of his reign he was greatly influenced by his mother Agrippina and tutor Lucius Annaeus Seneca. Nero preferred Seneca's advice to his mother's.

72 Colin Streeter, "Two Carved Reliefs by Aubert Parent", The J. Paul Getty Museum Journal, 13 (1985), 57. The motif is also known from a vase carved by Aubert Parent (84.SD.76) acquired by the J. Paul Getty Museum (1789). A grasshopper in a triumphal chariot drawn by parrot (psittacus) is depicted.

73 Compare the Latin locusta (f) with the English 'locust'. Locusta is also the Latin name for a certain species of short-horned grasshopper.

74 Domenico Monaco, A Complete Handbook to the National Museum in Naples (London: William Clowes and Sons, 1883), 3 .

75 The Natural History of Pompeii, 323

76 Fausto Niccolini, Felice Niccolini, Le case ed i monumenti di Pompei disegnati e

descritti, Band 3 (Neapel, 1890), T LVb. Also see the plate with a motif of a griffin alongside a motif of a parrot and grasshopper Raccolta delle più interessanti dipinture e de'più belli musaici rinvenuti negli scavi di Ercolano, di Pompei, e di Stabia che ammiransi nel Museo reale borbonico (Museo nazionale di Napoli, 1830).
3. The third motif with a chariot depicts a butterfly as the charioteer who is being pulled by an abstractly depicted stag beetle. No model for this painted motif has yet been found. (Fig. 9.)

4. In addition to the three scenes with chariots, there are two motifs with birds in the room. Another bird, that could be a parrot or a pigeon has also found its way to Vana-Võidu: a grey one standing on the edge of a jewellery basket holding a blue medallion in its beak (Fig. 10.) A model for the motif exists in Pompeii - in a floor mosaic in casa del Faun. (Fig. 15.) The mosaic was published by the brothers, Fausto and Felice Niccolini, in $1854 .{ }^{77}$ Several versions of the motif are known to exist, in which the jewellery basket is replaced by a box. ${ }^{78}$

5. The last figurative painting is a motif with a pigeon and a sealed letter, for which no ancient model has been found, although pigeons are often shown on ancient mosaics and can be found on coins and gems. At the same time, messenger pigeons were rare but not unknown in antiquity. ${ }^{79}$ (Fig. 8 .)

The ideological sources, painting techniques and skilful style of painting are very similar to the wall paintings of Suure-Kõpu and Vana-Võidu. The brothers also built their manor houses at the same time, so it is possible they used the same master from SouthernEurope for the paintings - the wall paintings have a similar and elaborately retouched style. Other similar elements include the marbled dado and dark wall panels, and figurative paintings copied from sample sheets. ${ }^{80}$ The first one had motifs from Pompeii and the second had at least partly from Herculaneum. ${ }^{81}$ The interior paintings and décor of Voltveti differs from the other two and the reception of ancient models seems to have gone farther than the Vana-Võidu and Suure-Kõpu manor houses.

77 Niccolini, Niccolini, Le case ed i monumenti di Pompei disegnati e descritti, Band 1, T II. 78 The motif with the bird and jewellery box appears in Saint-Non, Voyage Pittoresque monuments du Musée National de Naples gravés par les meilleurs artistes Italiens, 9, T 35.

79 It seems that the only known case of pigeons being used by Romans for communication outside of Egypt is in $43 \mathrm{BC}$, when Decimus Brutus was besieged in Mutina by Mark Antony, and pigeons (according to Frontinus, Strategemata, III, 13, 7-8) took messages to Brutus from the consul Hirtius, who was preparing to relieve the town. George Jennisson, Animals for Show and Pleasure in Ancient Rome (Manchester: Manchester University Press, 1937), 103.

80 For more about the self-portrait of the Suure-Kõpu artist, see Hiiop, "In the Footsteps of Classical Antiquity. Influences of the Antique in Estonian Manor Murals", 246.

81 Hiiop, "Antiigi peegeldus Eesti mõisamaalingutel”, 298. 


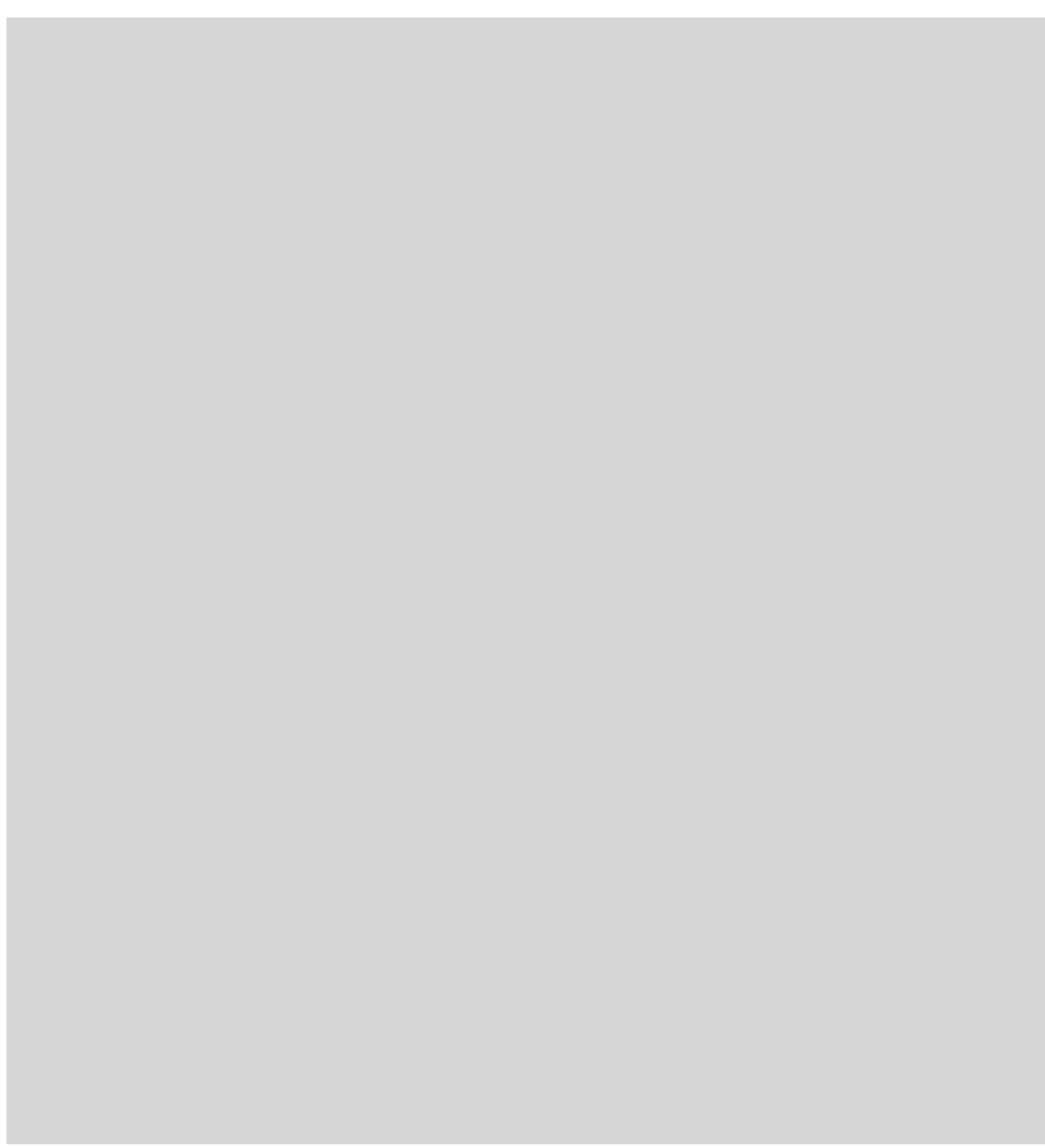

Fig. 14. Griffin and butterfly. Fausto Niccolini, Felice Niccolini, Le case ed i monumenti Pompei disegnati e descritti, Band 3 (Neapel, 1890), T LVb.

\section{CONCLUSION}

The Vana-Võidu, Suure-Kõpu and Voltveti manors belonged to three von Stryk brothers. Their manor houses were rebuilt in the late neoclassical style between 1830s and 1840s. It is obvious that the services of the same architect Emil Julius Strauss, who also designed the manor house of Alexander von Oettingen, a friend of the von Stryk brothers, were used in Vana-Võidu and Suure-Kõpu. Although the Voltveti manor house was built during the same period, it cannot be confirmed that it was designed by the same architect.

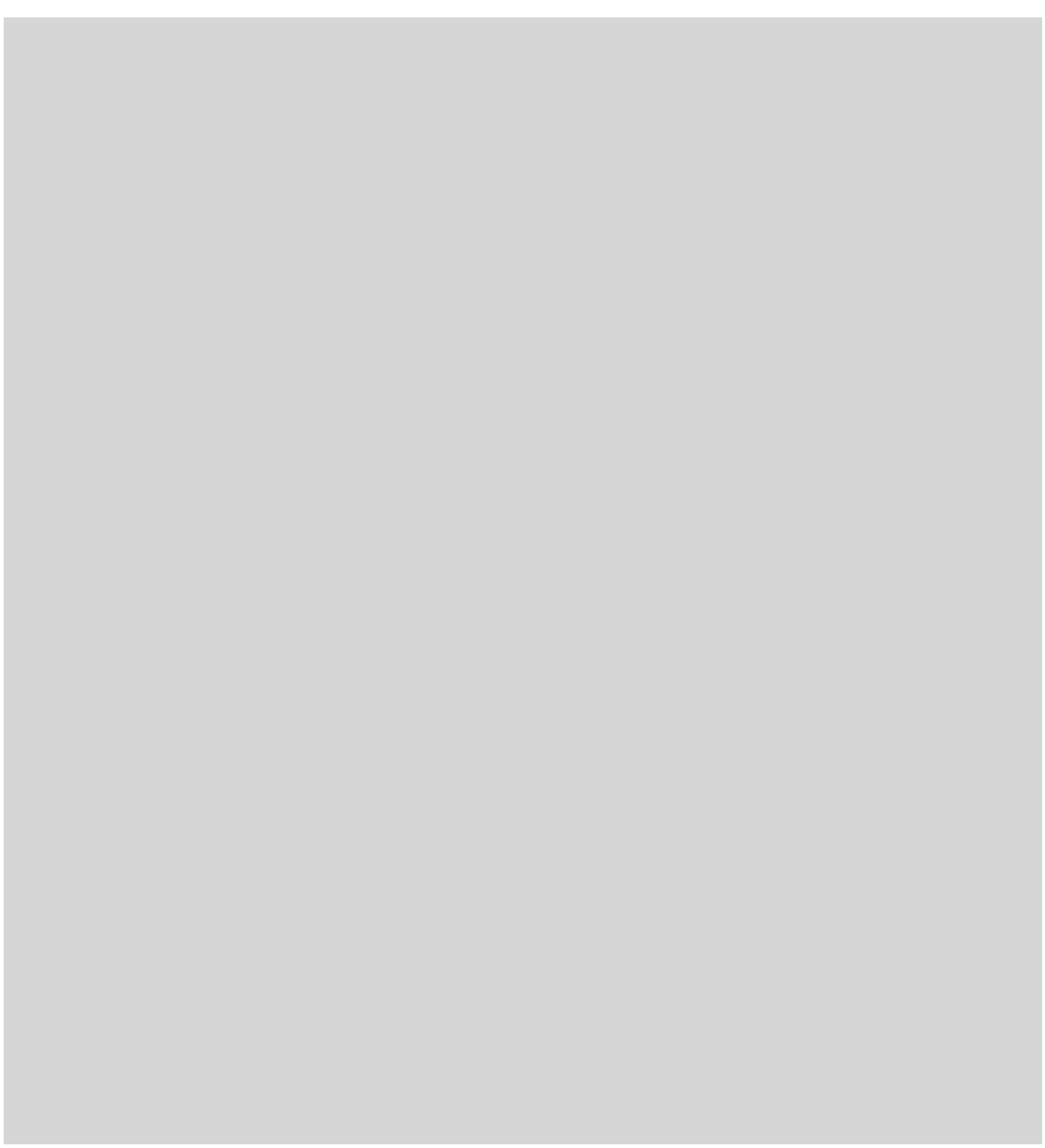

Fig. 15. Bird and jewellery basket. Fausto Niccolini, Felice Niccolini, Le case ed i monumenti di Pompei disegnati e descritti, Band 1 (Neapel, 1854), T II.

Around the middle of the $19^{\text {th }}$ century all three manor houses were given Pompeian-style interior decoration in their formal rooms. In Suure-Kõpu and Vana-Võidu, can see figurative paintings as well as the division of the walls into panels, which is characteristic of the Pompeian style. In Voltveti, there are no figurative paintings and the colour palette - alternating warm and cool pastel shades - is not characteristic of the Pompeian style. If the figurative paintings of Suure-Kõpu and Vana-Võidu mansions have adhered exactly the lines of the original models, in Voltveti antiquity has provided the inspiration, but the interior is rather similar to the Adams style. 
However, it should be considered that the information about Voltveti is incomplete, because the paintings have yet to be fully revealed and more information could be provided in the future.

The Vana-Võidu and Suure-Kõpu wall paintings are very similar both in style and technique: both figural scenes are very detailed and similar to the type of panel paintings that are rare in Livonian and Estonian manors. The figural scenes in Vana-Võidu and SuureKõpu are elaborately painted, unlike the ones in the University of Tartu Art Museum's paintings, which are cruder. It can be assumed that the brothers used the same master for wall paintings, as well as the same architect.

It is known that different publications about the excavated Campanian cities, like Pompeii, Herculaneum and Stabiae (Gell, Mazois, Zahn), were available in Estonia in the $19^{\text {th }}$ century. Apparently, the von Stryk brothers and the painter(s) were able to use the published motifs, because the figurative paintings at VanaVõidu and Suure-Kõpu are very accurately detailed. Undoubtedly, sample sheets were also used for painting the decorations and details in Voltveti.

One of the reasons for using such an interior design was a desire to be fashionable. The von Stryk brothers ran wealthy households thanks to their successful management and they could afford to rebuild the houses and install modern interiors. Certainly, they were familiar with the new trends outside Livonia, and this was a prerequisite for ordering an interior design that was popular, in all its different forms, in Germany and St. Petersburg.

The interiors at the Vana-Võidu, Suure-Kõpu and Voltveti manor houses include elements of the Pompeian style and form a unique triple Pompejanum in South-Estonia. And, at least in the case of VanaVõidu, there are probably more surprises to come. As this article was being completed, plans were being made to uncover more of the wall paintings.
JaAnika Anderson, Hilkka Hiiop: The Triple Pompejanum Possessed by the Von Stryk Family: The Manor Houses of Vana-Võidu, Suure-Kõpu and Voltveti

Keywords: Murals; Pompeian Style; Baltic-German Manor House; Conservation; Reception of Ancient Interior

\section{SUMMARY}

The article is inspired by the fascinating findings and conservation work done on the Pompeian style murals in Estonian manor houses during the last few decades. The focus is on the murals in the manor houses of Voltveti, Suure-Kõpu and Vana-Võidu - all of which belonged to different members of the von Stryk family of Baltic Germans. The article focuses on the figurative paintings and the style of the murals, as well as on an art-history-related interpretation and a wider contextual analysis of the Vana-Võidu wall paintings. These finds are the most recent, and this article will study the possible models and ideas for them, search for their art history context and importance among the triple Pompejanum of the von Strycks. The wall paintings in the Suure-Kõpu and Voltveti manor houses are used as reference material.

The Vana-Võidu, Suure-Kõpu and Voltveti manor houses were rebuilt in the late neoclassical style between 1830s and 1840s. The wall paintings in these late neoclassical manor houses were made during the second half of the 19th century and were inspired, in all cases, by a desire to achieve the look of an ancient interior. There are Pompeian-style murals in all three manors. In Suure-Kõpu and VanaVõidu, can see figurative paintings as well as the division of the walls into panels, which is characteristic of the Pompeian style. In Voltveti, there are no figurative paintings and the colour palette - alternating warm and cool pastel shades - is not characteristic of the Pompeian style, but the ornamental motives are derived from antiquity. It is known that different publications about the excavated Campanian cities, were available in Estonia in the $19^{\text {th }}$ century. Apparently, the von Stryk brothers and the painter(s) were able to use the published motifs, because the figurative paintings at Vana-Võidu and SuureKõpu are very accurately detailed. 


\section{CV}

Jaanika Anderson (b. 1978) received her PhD from the University of Tartu in 2015 as classical philologist. Her main research interests are the reception of ancient art, the history of collections and collecting, and literary criticism. She was the Curator of the Collection of Antiquities and organized exhibitions in the University of Tartu Art Museum starting in 2003. Jaanika Anderson is currently the Head of the University of Tartu Art Museum.

Hilkka Hiiop, PhD (b. 1974) is a professor in the Department of Conservation at the Estonian Academy of Arts, as well as a conservation specialist at the Art Museum of Estonia. She has studied and worked as a conservator in Berlin, Amsterdam and Rome, supervised a number of conservation and technical investigation projects in Estonia, curated exhibitions, and conducted scientific research on conservation and technical art history. 